\title{
The effect of reciting sholawat burdah on the anxiety level of parents with a hospitalized child in Tangerang district hospital, Indonesia
}

\author{
Mardiyanti Mardiyanti ${ }^{1 *}$, Uswatun $\mathrm{Khasanah}^{2}$, Anis Sanjaya ${ }^{3}$ \\ \{mardiyanti@uinjkt.ac.id, uswatun@uinjkt.ac.id, aniscssmora@gmail.com \\ *corresponding author \\ Faculty of Health Science, UIN Syarif Hidayatullah, Jakarta ${ }^{1,2,3}$
}

\begin{abstract}
Parents experience anxiety when their child is hospitalized which can negatively affect child's outcomes. Intervention designed to reduce anxiety is to use spiritual meditation such as reciting sholawat Burdah for Muslims. This study aims to determine the effect of reciting sholawat Burdah on the anxiety levels of parents with a hospitalized child. This research used a quasi-experimental design with a pretest posttest and a control group with 30 respondents. Interventions were given 3 days continuously. Anxiety was measured by using the Hamilton Anxiety Rating Scale (HARS) questionnaire. The average score of anxiety before intervention was 17.66 and after the intervention was 9.06. The Mann-Whitney test results showed that there were significant differences between the intervention group and the control group $(p=0.011)$ with the Cohen's D effect size was 0.96, which indicates that sholawat Burdah recitation has a great influence on the anxiety level of parents.
\end{abstract}

Keywords: anxiety, hospitalization, sholawat, spiritual meditation

\section{Introduction}

Child hospitalization is a stressful event which can create anxiety, distress and depression for parents [1-4]. Parents feel anxious because of their concerns for the child's safety, pain or discomfort and uncertainty with the child's outcomes [4]. Anxiety at the moderate level may affect physiologically (e.g., heart beat enhancement, no appetite), cognitively (e.g. confusion, reducing concentration) and behavior changes (e.g. difficulty sleeping, easy to get angry) thus may impair the nursing process during hospitalization [4-5].

Recent study showed that parents'high-level of anxiety is related to maladaptive coping and low parent self-efficacy: these are modifiable factors which can be targets for nursing intervention [3]. Coping support intervention works on emotional regulation which is delivered through activities that promote relaxation or distraction, these include yoga, music intervention [4] and reciting Qur'an [6].

Similar to Qur'an recitation, Sholawat Burdah recitation can be a form of mystical music that contributes to the release of endorphins by stimulating alpha brain wave, thus reducing anxiety and providing a relaxing effect [5][7]. Sholawat can also be in a form of dikr or remembrance of God and also a prayer for praising the Prophet Muhammad, Peace be Upon Him (pbuh) [7]. In syarah riyadussholihin and in the book of ihya' ulumuddin by Imam Ghozali it was explained that shalawat to the Prophet (pbuh) is part of the remembrance of the sharia and that it can calm the heart and eliminate anxiety [8]. This study aimed to investigate the effect 
of reciting sholawat Burdah to the parents 'level of anxiety during child hospitalization in Tangerang District hospital, Indonesia.

\section{Method}

This research was a quasi-experimental of pre- and post-test designs with control group. The number of samples in this study was 15 respondents in the control group and 15 respondents in the intervention group. Non-probability sampling techniques by purposive sampling were used in this study. The inclusion criteria included parents of hospitalized children in the pediatric ward Tangerang District hospital, parents who were Muslims and have anxious score between 14-41, which was measured by Hamilton Anxiety Rating Scale (HARS). After the patients agreed to participate, respondents were given a pre-test questionnaire. Then, they were provided with a booklet of sholawat burdah and were taught how to recite sholawat Burdah. Respondents recited sholawat together with the researcher in a pediatric ward for three consecutive days in the afternoon after Asr prayer time, for 10-15 minutes. After three days of intervention, the respondents were given post-test questionnaire. The respondents in the control group were given a questionnaire pre-test and post-test only after three days, and the time of data collection between the intervention and control group was different to avoid unethical issues. All the interventions were given after gaining ethical approval from the faculty ethic committee and the hospital ethic committee. All data were analyzed by using SPSS. Dependent $\mathrm{t}$-test was used for analyzed the data from the intervention group due to normal data distribution, whereas the Wilcoxon test was used for the control group due to abnormal data distribution. The mean difference between those two groups was compared by using Mann-Whitney test. All of those tests were tested at the alpha 0.05 and confidence level of $95 \%$.

\section{Result}

Table 1. The characteristics of parents with a hospitalized child in Tangerang District Hospital Pediatric Ward, Indonesia $2018(\mathrm{~N}=30)$

\begin{tabular}{|c|c|c|c|c|c|}
\hline \multirow{2}{*}{\multicolumn{2}{|c|}{ Characteristic }} & \multirow{2}{*}{\multicolumn{2}{|c|}{ Intervention group }} & \multirow{2}{*}{\multicolumn{2}{|c|}{ Control group }} \\
\hline & & & & & \\
\hline \multirow[t]{3}{*}{ Age } & $17-25$ & 3 & $20 \%$ & 5 & $33 \%$ \\
\hline & $26-35$ & 9 & $60 \%$ & 9 & $60 \%$ \\
\hline & $36-45$ & 3 & $20 \%$ & 1 & $7 \%$ \\
\hline \multirow{2}{*}{$\begin{array}{l}\text { Occupati } \\
\text { on }\end{array}$} & Work & 2 & $13 \%$ & 1 & $7 \%$ \\
\hline & $\begin{array}{l}\text { House- } \\
\text { wife }\end{array}$ & 13 & $87 \%$ & 14 & $93 \%$ \\
\hline \multirow{3}{*}{$\begin{array}{l}\text { Educatio } \\
\mathrm{n}\end{array}$} & Low & 4 & $27 \%$ & 4 & $27 \%$ \\
\hline & Middle & 11 & $73 \%$ & 10 & $66 \%$ \\
\hline & High & - & - & 1 & $7 \%$ \\
\hline \multirow[t]{2}{*}{ Disease } & Acute & 9 & $60 \%$ & 14 & $93 \%$ \\
\hline & Chronic & 6 & $40 \%$ & 1 & $7 \%$ \\
\hline Child age & $0-5$ & 10 & $67 \%$ & 10 & $67 \%$ \\
\hline
\end{tabular}




\begin{tabular}{llllll} 
& $6-11$ & 3 & $20 \%$ & 4 & $26 \%$ \\
Child & $12-16$ & 2 & $13 \%$ & 1 & $7 \%$ \\
place & 1st & 5 & $33 \%$ & 8 & $53 \%$ \\
& 2nd & 5 & $33 \%$ & - & - \\
& 3 rd & 4 & $26 \%$ & 3 & $33 \%$ \\
& 4 rd & 1 & $7 \%$ & 4 & $26 \%$ \\
Number & & & & & \\
of & 1 & 5 & $33 \%$ & 5 & $33 \%$ \\
children & 2 & 5 & $33 \%$ & 2 & $14 \%$ \\
& 3 & 3 & $20 \%$ & 2 & $14 \%$ \\
& $>4$ & 2 & $14 \%$ & 4 & $29 \%$ \\
$\begin{array}{l}\text { Days of } \\
\text { hospitali }\end{array}$ & 1 & 5 & $33 \%$ & 6 & $40 \%$ \\
zation & 2 & - & - & 2 & $13 \%$ \\
& 3 & 3 & $20 \%$ & 4 & $27 \%$ \\
& $>3$ & 7 & $47 \%$ & 3 & $20 \%$ \\
& & & & & \\
\hline
\end{tabular}

Table 1 shows demographic data from 30 parents of a hospitalized child in Tangerang District hospital. It shows that the majority of the mothers of a hospitalized child were housewives, aged between 17-35 years with low educational background. It also indicates that the majority of hospitalized children were under five years old.

Table 2. The anxiety level of parents with a hospitalized child in Tangerang District Hospital Pediatric Ward, Indonesia $2018(\mathrm{~N}=30)$

\begin{tabular}{lcccc}
\hline \multicolumn{1}{c}{ Anxiety level } & \multicolumn{2}{c}{ Intervention group } & \multicolumn{2}{c}{ Control group } \\
& Pre-test & post-test & Pre-test & post-test \\
\hline No anxiety & - & $12(80 \%)$ & - & $7(46 \%)$ \\
Mild anxiety & $13(86 \%)$ & $3(20 \%)$ & $13(86 \%)$ & $8(53 \%)$ \\
Moderate & $2(14 \%)$ & - & $2(14 \%)$ & - \\
high & - & - & - & - \\
\hline
\end{tabular}


Table 2 shows that there is similar number of respondents in the pre-test between intervention and control group. However, after post-test shows that the majority of respondents in the intervention group was in no anxiety level whereas the control group was in no anxiety and mild anxiety.

Table 3. The anxiety level of parents with a hospitalized child in the intervention group in Tangerang District Hospital Pediatric Ward, Indonesia $2018(\mathrm{~N}=15)$

\begin{tabular}{lcllllll}
\hline $\begin{array}{l}\text { Interventi } \\
\text { on }\end{array}$ & $\mathrm{n}$ & mean \pm SD & $\begin{array}{c}\text { difference } \\
\pm \mathrm{SD}\end{array}$ & Min-max & $\mathrm{p}$ & $\mathrm{t}$ & eta \\
\hline Pre & 15 & $\begin{array}{l}17,66 \pm 2, \\
84\end{array}$ & $8,6 \pm 4,25$ & $14-25$ & 0,000 & 7,828 & 0,814 \\
Post & 15 & $9,06 \pm 4,4$ & & $2-17$ & & & \\
& & 3 & & & & & \\
& & & & & & \\
\hline
\end{tabular}

Table 3 shows that the anxiety score decreased from 17.66 to 9.06 with $p$-value $<0.5$ (significance), t-test ratio 7.828 and eta square for effect size is 0.814 , which indicates the effect size was large.

Table 4. The anxiety level of parents with a hospitalized child in the control group in Tangerang District Hospital Pediatric Ward, Indonesia $2018(\mathrm{~N}=15)$

\begin{tabular}{lccccc}
\hline $\begin{array}{l}\text { Interventi } \\
\text { on }\end{array}$ & $\mathrm{n}$ & mean \pm SD & Min-max & $\mathrm{Z}$ & Asymp. Sig (2-tailed) \\
\hline Pre & 15 & $16,26 \pm 3,1$ & $14-24$ & & 0,10 \\
Post & 15 & $12,93 \pm 3,57$ & $5-17$ & & \\
\hline
\end{tabular}

Table 4 indicates that the anxiety level in control group was decreased from 16.26 to 12.93 , but the p-values was 0.1 , which means that the decrease was not significant.

Table 5. The mean difference of anxiety level of parents with a hospitalized child in the intervention and control group in Tangerang District Hospital Pediatric Ward, Indonesia 2018

$(\mathrm{N}=30)$

\begin{tabular}{llcccc}
\hline Time & group & n & mean \pm SD & $\begin{array}{c}\text { Asymp.Si } \\
\text { g }(2- \\
\text { tailed })\end{array}$ & $D$ \\
\hline Pre & Intervention & 15 & $17,66 \pm 2,84$ & 0,061 & 0,470 \\
& Control & 15 & $16,26 \pm 3,1$ & & \\
Post & Intervention & 15 & $9,06 \pm 4,43$ & 0,011 & 0,961
\end{tabular}


Control $\quad 15 \quad 12,93 \pm 3,57$

Table 5 presents the mean of anxiety score in the intervention group was 17.66 and the control group was 16.26 with no significant difference in the pretest. However, after posttest the mean difference of both groups was significant with 9.06 for the intervention group and 12.93 for the control group. The effect size of pretest was 0.47 (medium), whereas in the posttest it was 0.961 (large).

\section{Discussions}

Statistical test analysis shows that reading Shalawat Burdah can significantly lower the level of parental anxiety towards child hospitalization $(p<0.05)$ with a greater influence $(\eta>$ 0.14). Meanwhile, in the control group, there was no significant effect of standard hospital treatment on the anxiety levels of parents ( $p>0.05)$. In addition to the data, the average difference in posttest anxiety scores between the control group and the intervention group shows significance value of $<0.05$ which means there was a significant difference in the anxiety score between the two groups during the posttest, and found an effect size of $0.96(\mathrm{~d}>0.8)$ indicating that reading Shalawat Burdah had a greater effect on the anxiety levels of parents with a hospitalized child than the control group that received standard hospital treatment. These may be influenced by the demographic factors the respondents have. These include the anxiety level before treatment, the type of the disease and days of stay in the hospital.

The majority of the respondents come from a mild anxiety level before the intervention was given, this may influence the large effect of sholawat burdah. It was also more common for the children to have an acute disease than a chronic disease. The parents of sick children with an acute disease usually have lower anxiety rather than parents with children with a chronic disease because it can lead to death, the outcome is uncertain and there is a high financial problem due to a long hospitalization [9]. In addition, respondents who were met during their first day of hospitalization usually had higher anxiety than those who had already stayed for a couple of days because of their adaptation to the hospitalization and condition [5][9].

Nevertheless, sholawat Burdah is a part of meditation techniques which focused on emotional regulation by improving the relation between individual and their God. These techniques inhibit the formation of stress responses, especially in the nervous system and hormones. The effect of meditation is to increase the alpha brain waves found in relaxing body conditions [7][10]. Ultimately, relaxation can lower physiological tension [11]. This research is in accordance with research conducted by Manzoni, et al who have conducted a meta-analysis of relaxation that shows that consistent relaxation exercises can significantly reduce anxiety [12]. Moreover, Sholawat Burdah has its own history of Imam Al Bisri, who suffered from an unknown disease that caused him paralysis for years. He wrote a poem to Prophet Muhammad (pbuh) to show his compassion and praise; this poem claimed as wasilah (intermediary) for the prayer to God to be able to recover from the disease. After the poem was made, Imam Al Bisri dreamed he met Prophet Muhammad (pbuh) who gave him a long coat (called Burdah). After 
he woke up, he found out that he had recovered from the disease and was able to walk again [13-14].

Other research states that reading shalawat can increase spiritual value and can affect perception so as to prevent negative stress (distress) and to become positive (eustress) [15]. In addition, by reading shalawat with circadian rhythms the body can affect the limbic system and adrenal cortex thus stimulating cortisol down and making people feel comfortable, fostering positive perception and improving individual wellness [7].

\section{Conclusion}

The average level of parent anxiety scores with children who experienced hospitalization before intervention or during pretest and posttest is as follows: Intervention group anxiety score from 17.66 (moderate anxiety) to 9.06 (no anxiety). Whereas in the control group the anxiety score from 16.26 (moderate anxiety) to 12.93 (no anxiety). This study shows that reciting Shalawat Burdah significantly affects parents' anxiety and Shalawat Burdah reading techniques have a great influence on lowering anxiety.

\section{References}

[1] Franck LS, Wray J, Gay C, Dearmun AK, Lee K, Cooper BA. Predictors of parent post-traumatic stress symptoms after child hospitalization on general pediatric wards: a prospective cohort study. Int J Nurs Stud. 2015 Jan;52(1):10-21. doi: 10.1016/j.ijnurstu.2014.06.011. Epub 2014 Jul 5. PMID: 25047550.

[2] Oxley R. Parents' experiences of their child's admission to paediatric intensive care. Nurs Child Young People. 2015 May;27(4):16-21. doi: 10.7748/ncyp.27.4.16.e564. PMID: 25959486.

[3] Rosenberg RE, Clark RA, Chibbaro P, Hambrick HR, Bruzzese JM, Feudtner C, Mendelsohn A. Factors Predicting Parent Anxiety Around Infant and Toddler Postoperative and Pain. Hosp Pediatr. 2017 Jun;7(6):313-319. doi: 10.1542/hpeds.2016-0166. Epub 2017 May 16. PMID: 28512138; PMCID: PMC5469249

[4] Doupnik SK, Hill D, Palakshappa D, Worsley D, Bae H, Shaik A, Qiu MK, Marsac M, Feudtner C. Parent Coping Support Interventions During Acute Pediatric Hospitalizations: A MetaAnalysis. Pediatrics. 2017 Sep;140(3):e20164171. doi: 10.1542/peds.2016-4171. Epub 2017 Aug 17. PMID: 28818837; PMCID: PMC5574731.

[5] Kiptiyah, M., \& Mutikasari. (2013). Tingkat Kecemasan Keluarga Pasien di Ruang ICU. FIK UI, (27).

[6] Ghiasi A, Keramat A. The Effect of Listening to Holy Quran Recitation on Anxiety: A Systematic Review. Iran J Nurs Midwifery Res. 2018 Nov-Dec;23(6):411-420. doi: 10.4103/ijnmr.IJNMR_173_17. PMID: 30386389; PMCID: PMC6178573.

[7] Maksum, Muhammad \& el Kaysi, A. F. (2009). Rahasia Shalawat Rasulullah SAW. Yogjakarta: Mutiara Media.

[8] Salim, A. U. (2005). Syarah Riyadush Shalihin. (A. Ghofar, Ed.). Jakarta: Pustaka Imam.

[9] Renylda, R. (2018). Kecemasan Orang Tua pada Anak dengan Thalasemia di Poli Anak Rumah Sakit Umum Daerah H. Abdul Manap Kota Jambi Tahun 2015. Jurnal Ilmiah Universitas Batanghari, 18(1), 110-115.

[10] Maghfiroh, N. . (2015). Efektifitas terapi relaksasi meditasi dalam menurunkan tingkat stres.

[11] Asmadi. (2006). Teknik Prosedur Keperawatan Konsep dan Aplikasi Kebutuhan dasar Klien. Jakarta: Salemba medika.

[12] Manzoni, Pagnini, \& Castelnuovo. (2008). Relaxation training for anxiety:a ten years systematic review with meta-analysis. 
[13] Abdan, S. (2011). Qoshidah Burdah. Surabaya: Muara Progresif.

[14] Adib, M. (2009). Burdah. Yogjakarta: Pustaka Pesantren.

[15] Utami, T. N. (2017). Tinjauan Literatur Mekanisme Zikir Terhadap Kesehatan: Respons Imunitas. Jurnal JUMANTIK, 2(1), 100-110. 